\title{
Investigation of the Occurrence of Abnormal Oral Glucose Tolerance (OGT) Level among People of Nasarawa State Polytechnic, Lafia
}

\author{
Habibu Tanimu ${ }^{1,2}$ and Ashefo Daniel Paul ${ }^{1}$ \\ ${ }^{1}$ Science Laboratory Technology Department, School of Science and Technology, Nigeria \\ ${ }^{2}$ Biochemistry Department, School of Sciences Jain, India
}

Submission: February 11, 2019; Published: April 17, 2019

*Corresponding author: Habibu Tanimu, Chemistry/Biochemistry unit, Science Laboratory Technology Department, School of Science and Technology, Nasarawa State Polytechnic, P.M.B. 109, Ombi 1, Jos Road, Lafia, Nigeria

\begin{abstract}
Diabetes is an important chronic disease both in terms of prevalence and associated morbidity and early mortality. Mortality rates in diabetics are two - to three-fold higher than those without diabetes, it is a large, growing and costly public health problem and over 50\% of persons with prediabetes are detected only by Oral Glucose Tolerance (OGT) findings. One hundred and sixty-eight (168) subjects comprising of fifty-six (56) adult males and one hundred and twelve (112) adult females of Nasarawa State Polytechnic Lafia were used to assess the Occurrence of (IGT) by subjecting them to an Oral Glucose Tolerance Test (OGTT). (OGTT) gives us more information on the likelihood of being diabetic by showing a pre diabetic concentration of glucose in the blood. From the findings in this research, All the 56 males and the 112 females have their fasting Blood Glucose Level (BGL) within normal range, but for 2-hour (BGL), 7 Males (12.5\%) and 12 females (11.0\%) showed an (IGT) of (7.8mmol/L $-9.6 \mathrm{mmol} / \mathrm{L})$ and $(8.0 \mathrm{mmol} / \mathrm{L}-15.9 \mathrm{mmol} / \mathrm{L})$ respectively. Looking at the result based on \pm Standard Deviation (SD), Females have elevated 2-hour Glucose concentration $(6.19 \mathrm{mmol} / \mathrm{l} \pm 0.34 \mathrm{mmol} / \mathrm{l}$ which indicate IGT) than Males $(5.15 \mathrm{mmol} / \mathrm{l} \pm 0.22 \mathrm{mmol} / \mathrm{l})$ significant $(\mathrm{P}<0.05)$. It will be very appropriate for people particularly adults to check their OGT level from time to time for early detection of IGT the silent metabolic disorder that precedes progression to active diabetes.

Keywords: Impaired glucose tolerance; Diabetes mellitus; Hyperglycemia; Prediabetic; Blood glucose level

Abbrevations: DM: Diabetes Mellitus; IGT: Impaired Glucose Tolerance; OGTT: Oral Glucose Tolerance Test; BG: Blood Glucose Level; OGT: Oral Glucose Tolerance; T2DM: Type 2 Diabetes Mellitus; CVD: Cardiovascular Disease; NIDDM: Non-Insulin Dependent Diabetes Mellitus; WHO: World Health Organization; IDF: International Diabetes Federation; NHANES: National Health and Nutrition Examination Survey; NPC: National Population Commission; SPSS: Statistical Package for Social Sciences; IBM: International Business Machine; SD: Standard Deviation; BMI: Body Mass Index; TETFUND: Tertiary Education Trust Fund; ADA: American Diabetes Association
\end{abstract}

\section{Introduction}

Diabetes Mellitus (DM) or simply Diabetes can be defined as a metabolic disorder clinically characterized by hyperglycemia due to defective insulin secretion, defective insulin action or both. The chronic hyperglycemia of Diabetes is associated with long term damage, dysfunction and failure of different organs especially the eyes, kidneys, nerves, heart and blood vessels [1].

One of the five main courses of death in the world is DM [2], the most common form of Diabetes, which account for $90-95 \%$ of all Diabetic cases. DM, particularly Non-Insulin Dependent Diabetes Mellitus (NIDDM) is increasingly common throughout the world. World Health Organization has predicted that between
1997 and 2025 the number of people suffering from diabetes will double from 143million to 300million [3].

\section{Oral glucose tolerance test (OGTT)}

Test widely used for glucose tolerance classification is the Oral Glucose Tolerance Test (OGTT), it measures the body's ability to metabolized glucose [4] it is a specialized metabolic investigation that involve serial timed measurement of plasma/Blood Glucose, Concentration and post oral glucose load [5].

It is an investigation for the detection of early derangement to absolute or relative deficiency of insulin resulting in hyperglyce- 


\section{Current Research in Diabetes \& Obesity Journal}

mia, such disorders produce social and economic problem particularly in developing countries [6-9].

OGTT which for its simplicity is the method suitable for large studies, provides information on insulin secretion and action but does not directly yield a measure of insulin sensitivity [10].

The main reason for performing OGTT is to diagnose Impaired Glucose Tolerance (IGT) or diabetes by virtues of 2-h value, both of these are risk factors for Cardiovascular Disease (CVD) and IGT predicts the development of type two Diabetes Mellitus (T2DM), as well as vascular complication and even death in individual which show high risk indicators $[11,12]$.

The alarming increase in the prevalence of diabetes and rate of mortality due to this disease was reported by many studies $[13,14]$. In yet another study the prevalence of diabetes is predicted to double globally in 2030 with a maximum increase in India [15] and it is predicted that by 2030 diabetes mellitus may afflict up to 79.4 Million in India [15].

The prevalence of both NIDDM and occurrence of Glucose Tolerance increase with age. It is estimated that between 25-30\% of the United State (US) population aged 65years and older has NIDDM or impaired glucose tolerance (ie decreased glucose disposal rate as determine by an Oral Glucose Tolerance Test) [16]. (OGTT) is said to be one of the best methods for the diagnosis of the likely hood of becoming diabetic [17].

\section{Impaired glucose tolerance (IGT)}

This a pre-diabetic state of hyperglycemia that is associated with insulin resistance and increased risk of cardiovascular pathology. IGT may precede diabetes mellitus by many years [18]. Although, some drugs can delay the onset of diabetes, lifestyle modifications play a greater role in the prevention of diabetes $[19,20]$. Persons identified as having an IGT should exercise regularly, loss of 5 to $7 \%$ of the body and reduce intake of sugar to an appreciably reduced limit and highly processed Carbohydrate (junk food) [18], OGTT result usually shows a peak and decay in glucose levels which may indicate involvement of many factors, such as insulin sensitivity, glucose intestinal absorption rate, $ß$-cell function and components, etc. [21].

\section{Interpretation of OGTT results}

Fasting plasma glucose (measured before the OGTT begins) should be below $6.1 \mathrm{mmol} / \mathrm{L}(110 \mathrm{mg} / \mathrm{dl})$, fasting levels between 6.1 and $7.0 \mathrm{mmol} / \mathrm{L}$ (110 and 126mg/dl) are borderline (impaired fasting Glycaemia) and fasting levels repeatedly at or above $7.0 \mathrm{mmol} / \mathrm{L}(126 \mathrm{mg} / \mathrm{dl})$ are diagnostic of diabetes [22].

A 2hours OGTT glucose level below $7.8 \mathrm{mmol} / \mathrm{L}(140 \mathrm{mg} / \mathrm{dl})$ is normal, whereas higher glucose levels indicate hyperglycemia. Blood glucose between $7.8 \mathrm{mmol} / \mathrm{L}(140 \mathrm{mg} / \mathrm{dl})$ and $11.1 \mathrm{mmol} / \mathrm{L}$ $(200 \mathrm{mg} / \mathrm{dl})$ indicates "impaired glucose tolerance", and levels above $11.1 \mathrm{mmol} / \mathrm{L}(200 \mathrm{mg} / \mathrm{dl})$ at 2 hours confirms a diagnosis of diabetes [22].

\section{Aim of the Research}

The aim of this research is to investigate the occurrence of OGT Level among people of Nasarawa State polytechnic, Lafia

\section{Objectives of the Research}

a) To determine the Oral Glucose Tolerance Level at $30 \mathrm{~min}$ interval, for a period of $2 \mathrm{hrs}$.

b) To find out the pattern of the Glucose Tolerance among the population ie adult males and females investigated.

c) To find out people that have a prediabetic condition ie IGT.

d) To create awareness to the public on the importance of OGTT.

\section{Justification of the Research}

a. Due to rising prevalence of diabetes mellitus (particularly Type 2) among people all over the world, detecting and treating this disorder as early as possible has become a top public health priority. Preventing this disorder can significantly decrease health care cost [23].

b. Diabetes is a large, growing and costly public health problem and over $50 \%$ of persons with prediabetes are detected only by IGT findings [24].

c. National and international randomized controlled trials have shown that diabetes can be delayed or prevented among persons with IGT. [24].

\section{Materials and Methods}

\section{Study area}

This study was carried out at Nasarawa State Polytechnic, Lafia. Lafia is the headquarters of Nasarawa State Nigeria, West Africa [25]. Lafia is located in North Central Geopolitical zone of Nigeria. The town is densely populated with 330,712 inhabitants. It is located on the latitude $8031^{\prime} \mathrm{E}$ [25].

\section{Exclusion criteria}

Participants that are diagnosed from fasting samples with glucose concentration of $\geq 7.0 \mathrm{mmol} / \mathrm{L}$ are excluded from the research, ie those participants that appear diabetic by the fasting blood glucose concentration.

\section{Study population}

One Hundred and Sixty-Eight (168) participants were used in this research comprising of Fifty-Six (56) adult males and one hundred and twelve (112) adult Females after informed consent. Nasarawa State Polytechnic Clinic Lafia was used to carry out this research.

\section{Patients' Preparation for OGTT}

a) In this research the patients that consented for the study were adequately prepared as thus:- 


\section{Current Research in Diabetes \& Obesity Journal}

b) The participants were given adequate explanation on the purpose and procedure of the test.

c) They are asked to withdraw all medication that are known to influence OGTT Results if at all on Medication.

d) They were asked to fast overnight ie for $10-12 \mathrm{hrs}$

e) They were told to make themselves available for the test between 8 and 10am the following Morning.

f) They should not get involve in strenuous exercise during the fast and test period.

g) They were told not to smoke, ingest coffee (caffeine), alcohol during preparation and test period. [26].

\section{Procedure for OGTT}

Participants were told to rest for about Thirty minutes (30min) on arrival to the laboratory before the commencement of the OGTT investigation.

A Zero-time (baseline) blood sample was collected via finger prick and tested using a hand held (Glucometer Accu - Check(R) Active) for fasting blood glucose level. This is to screen for our potential candidate that are not diabetic, while the remaining 2-hour blood samples that were collected are venous blood samples.

The participants were then given Seventy-five grams (75g) of glucose solution to drink within Five minutes (5mins) time frame after the fasting glucose test.

Blood samples were drawn at intervals of $30 \mathrm{mins}$ for two (2hours) for measurement of blood glucose concentration. The blood samples were collected on a cannulated hand of the participants [26].

\section{Statistical analysis}

Statistical Package for the Social Science software (SPSS v 16; IBM/SPSS Inc., Chicago, IL, USA) was used to perform all calculations. Glucose concentration data are presented as mean \pm Standard Deviation. The alpha level was set at 0.05 for all test of statistical significance.

\section{Results}

The results of the research are presented in Table 1-3 and Figures 1-3 below: -

Table 1: Showing changes in concentrations of blood glucose ( $\mathrm{mmol} / \mathrm{L}$ ) at different time intervals in Males.

\begin{tabular}{|c|c|c|c|c|c|}
\hline Subjects & $\begin{array}{c}\text { FBG (0 } \\
\text { Min) }\end{array}$ & 30 Min & $\mathbf{6 0}$ Min & $\mathbf{9 0}$ Min & $\mathbf{1 2 0}$ Min \\
\hline Male & $\begin{array}{c}3.92 \pm \\
0.11\end{array}$ & $\begin{array}{c}5.45 \pm \\
0.14\end{array}$ & $\begin{array}{c}6.12 \pm \\
0.15\end{array}$ & $\begin{array}{c}5.61 \pm \\
0.18\end{array}$ & $\begin{array}{c}5.15 \pm \\
0.22\end{array}$ \\
\hline
\end{tabular}

Table 2: Showing changes in concentrations of blood glucose ( $\mathrm{mmol} / \mathrm{L}$ ) at different time intervals in Females.

\begin{tabular}{|c|c|c|c|c|c|}
\hline Subjects & $\begin{array}{c}\text { FBG (0 } \\
\text { Min) }\end{array}$ & 30 Min & 60 Min & 90 Min & 120 Min \\
\hline \multirow{2}{*}{ Female } & $3.42 \pm$ & $5.91 \pm$ & $6.69 \pm$ & $6.54 \pm$ & $6.19 \pm$ \\
& 0.10 & 0.20 & 0.25 & 0.28 & 0.34 \\
\hline
\end{tabular}

Table 3: Showing changes in concentrations of blood glucose $(\mathrm{mmol} / \mathrm{L})$ at different time intervals in both Males and Females.

\begin{tabular}{|c|c|c|c|c|c|}
\hline Subjects & $\begin{array}{c}\text { FBG (0 } \\
\text { Min) }\end{array}$ & 30 Min & $\mathbf{6 0}$ Min & $\mathbf{9 0}$ Min & $\mathbf{1 2 0}$ Min \\
\hline \multirow{2}{*}{ Male } & $3.92 \pm$ & $5.45 \pm$ & $6.12 \pm$ & $5.61 \pm$ & $5.15 \pm$ \\
& 0.11 & 0.14 & 0.15 & 0.18 & 0.22 \\
\hline \multirow{2}{*}{ Female } & $3.42 \pm$ & $5.91 \pm$ & $6.69 \pm$ & $6.54 \pm$ & $6.19 \pm$ \\
& 0.10 & 0.20 & 0.25 & 0.28 & 0.34 \\
\hline
\end{tabular}

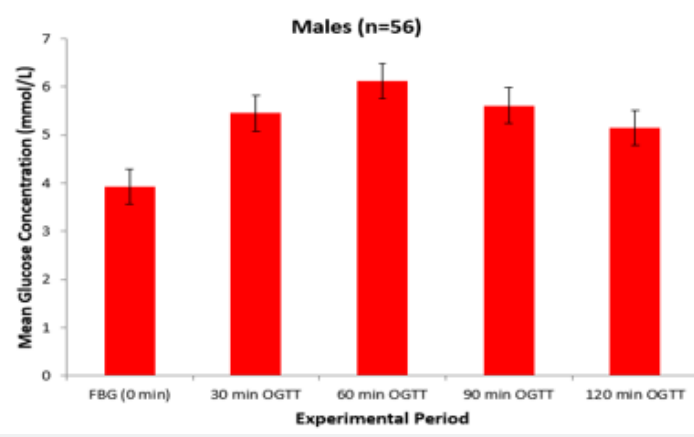

Figure 1: Bar Chart showing changes in concentrations of blood glucose $(\mathrm{mmol} / \mathrm{L})$ at different time intervals in Males.

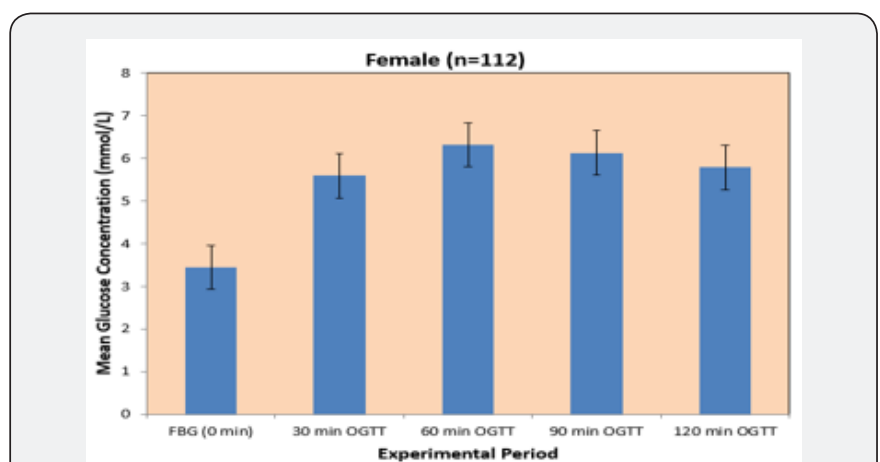

Figure 2: Bar chart showing changes in concentrations of blood glucose $(\mathrm{mmol} / \mathrm{L})$ at different time intervals in females.

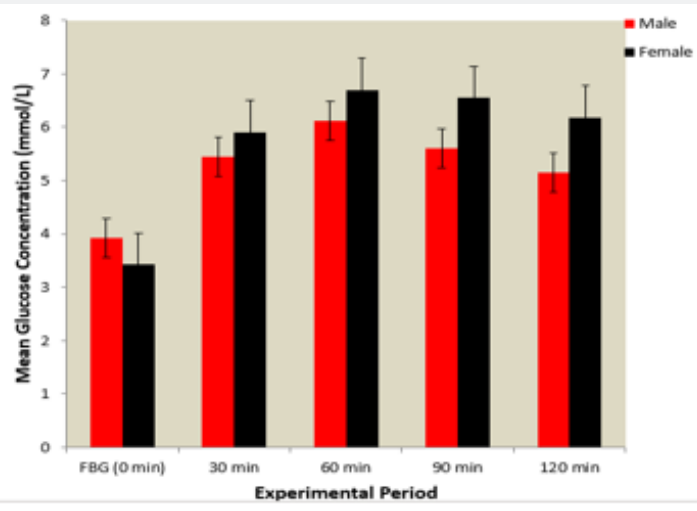

Figure 3: Bar chart showing changes in concentrations of blood glucose $(\mathrm{mmol} / \mathrm{L})$ at different time intervals in both Males and Females.

\section{Discussion}

Diabetes mellitus represent a significant burden on the health care system of Nigeria. Thus, IGT which is a silent metabolic disor- 
der that appear before active diabetic condition need to be given a serious attention [23].

Analysis of the findings in this experiment is a simple one. The Blood Glucose Level (BGL) at 30min, 60min, 90min and $120 \mathrm{~min}$ were compared with initial/ baseline ( $0 \mathrm{~min})$ BGL of their respective groups ie Females and Males. The BGL after the glucose load reached its peak at $60 \mathrm{~min}$ and decreased subsequently over time for both the males and females.

All the 56 males and the 112 females involved in this research have their fasting BGL $(2.85 \mathrm{mmol} / \mathrm{L}-5.5 \mathrm{mmol} / \mathrm{L})$ and (2.0 $\mathrm{mmol} / \mathrm{L}-5.5 \mathrm{mmol} / \mathrm{L})$ respectively within normal range, but for 2-hour BGL, 7 males (12.5\%) and 12 females (11.0\%) showed an impaired Glucose Tolerance IGT $(7.8 \mathrm{mmol} / \mathrm{L}-9.6 \mathrm{mmol} / \mathrm{L})$ and $(8.0 \mathrm{mmol} / \mathrm{L}-15.9 \mathrm{mmol} / \mathrm{L})$ respectively as reported by [22].

Four (4) female participants have their 2-hour BGL ranging from $(11.1 \mathrm{mmol} / \mathrm{L}-15.9 \mathrm{mmol} / \mathrm{L})$ which indicate that they are diabetic as stated by [22], despite the fact that they have normal Glucose concentration ranging from $(3.4 \mathrm{mmol} / \mathrm{L}-5.5 \mathrm{mmol} / \mathrm{L})$. No male participant showed BGL of 11 . mmol/L which is the minimum value that classify individuals to be diabetic as reported by [22]. This finding conforms to the fact that more men than women have elevated fasting blood glucose (Impaired Fasting Glycaemia (IFG). Whereas more women than men have elevated 2- hour Glucose concentrations (Impaired Glucose Tolerance. (IGT) [27-29].

Looking at the results in terms of mean \pm Standard Deviation (SD), Males have elevated fasting glucose level $(3.92 \mathrm{mmol} / \mathrm{l} \pm$ $0.11 \mathrm{mmol} / \mathrm{l})$ than Females $(3.42 \mathrm{mmol} / \mathrm{L} \pm 0.10 \mathrm{mmol} / \mathrm{L})$ which is not significant $(\mathrm{P}<0.05)$, in one study it was shown that people with elevated 30min Post Glucose load are prone to having increased prevalence of impaired fasting glucose [30] Females have elevated 2-hour Glucose concentration $(6.19 \mathrm{mmol} / \mathrm{l} \pm 0.34 \mathrm{mmol} / \mathrm{l}$ which indicate IGT) than Males $(5.15 \mathrm{mmol} / \mathrm{l} \pm 0.22 \mathrm{mmol} / \mathrm{l})$ which is significantly different $(\mathrm{P}<0.05)$. The occurrence of Impaired Glucose tolerance is found to be high in both males and females but significantly higher $(\mathrm{P}<0.05)$ in females than males in this research which means they are unknowingly prone to diabetes prior to this investigation. OGTT is a useful tool in the diagnosis of IGT but it will not be sufficient to understand the pathogenesis of T2DM without other accompanying investigation(s) [31].

The average BGL after glucose load ie from $30 \mathrm{~min}, 60 \mathrm{~min}$, $90 \mathrm{~min}$ and $120 \mathrm{~min}$ in Males drop much more than that in females (Figure 3).

It has been suggested that part of the sex differences in 2hour glucose concentrations is related to the different body sizes of men and women [27,29,32]. In General, women have a smaller body mass than men, which means it may take them longer time to metabolize the $75 \mathrm{~g}$ of glucose given during the standard (OGTT). On the other hand, the sex difference in glucose concentration in the fasting state are likely to be cause by physiological differences eg sex hormone.
From this research it could be seen that many people have impaired Glucose tolerance but do not care to find out either due to ignorance of this type of investigation or due to the fact that OGTT is not a routine test in most of our medical laboratories even in the tertiary health facilities in Nigeria. This also indicate that some early onset of diabetes might not be detected by fasting glucose level alone.

\section{Conclusion}

The findings in this research showed that, impaired glucose tolerance was present in both the non-diabetic Males and Females participants investigated. These people could easily escape routine screening procedures which may not be useful in early identification of potential future Diabetes. It will be very appropriate for people particularly adults to check their OGT level from time to time for early detection of IGT the silent metabolic disorder that precedes progression to active diabetes.

\section{Recommendation}

Impaired glucose had a positive correlation with Body Mass Index (BMI), as such:-

a) Exercise and Nutrition hence life style modification with emphasis on physical activity should be advocated for in the society.

b) People should be regularly checking their glucose level particularly using OGTT to be able to detect any possible onset of impaired glucose tolerance that will progress to diabetes.

\section{Acknowledgement}

We are grateful to all volunteers who participated in this research particularly staff of Nasarawa State Polytechnic, Lafia and the Staff of Nasarawa State Polytechnic Medical Laboratory for their support. We are also thankful to Nigeria Tertiary Education Trust Fund (TETFUND) for funding the research.

\section{References}

1. American Diabetes Association (2010) Diagnosis and classification of diabetes mellitus. Diabetes care 3(1): S62-S69.

2. Kannel WB, McGee DL (1979) Diabetes and cardiovascular diseases. The Framingham study. JAMA 241(19): 2035-2038.

3. (1998) The world Health Report; Life in the $21^{\text {st }}$ Century a vision for all. World Health Organization (WHO), Geneva, USA.

4. Islam MA, Akhtar MA, Khan MRI, Hossain MS, Alam AHMK, et al. (2009) Oral Glucose Tolerance Test in Normal control and glucose induced hyperglycemic rat with coccina cordifolia I and catharanthus Roseus L. Pak J Pharm Sci 22(4): 402-404.

5. Sacks DB (1999) Carbohydartes. In: Burtis CA, Ashwood ER (Eds.), Tietz Textbook of Clinical Chemistry, ( $3^{\text {rd }}$ edn.), W.B Saunders co. Philadelphia, USA, pp. 750-808.

6. Singh DL Bharttai MD, Maskey A (1994) Demographic Profile of diabetes patients admitted to the medical wards of Bir Hospital, Nepal, 1990-1994. Int Diab Digest 4: 87-88.

7. Okesina AB, Bojuwoye BJ, Gadzama AA, Ogunriola EO (1999) Prevalence and sex distribution of complications in diabetic patients from Illorin, Nigeria. Int Diab Digest 3: 63-64. 
8. Mayes W (1993) Fighting a global epidemic with simple weapon. IDF Bulleting 38: 4.

9. Park JE, Park K (1991) Park's textbook of social and preventive medicine. Jabal pur: Banasidas, Bhanot, pp. 257-260.

10. Mari A, Pacini G, Murphy E, Luduic B, Nolan JJ (2001) A model-based method for assessing insulin sensitivity from the oral glucose tolerance test. Diabetes care 24(3): 539-548.

11. Davidson MB Counterpoint (2002) The oral glucose tolerance test is superflous. Diabetes Care 25(10): 1883-1885.

12. Bergman M, Manco M, Sesti G, Dankner R, Pareek M, et al. (2018) Petition to replace current OGTT criteria for diagnosing prediabetes with the 1-hour post-load plasma glucose $\geq 155 \mathrm{mg} / \mathrm{dl}(8.6 \mathrm{mmol} / \mathrm{L})$ Diabetes Res Clin Pract 146: 18-33.

13. Naidu KC (2003) Plant in India and Herbal based antidiabetic. Research Regency Publication, pp. 4-6.

14. Bharah DR, Pal R, Kar S, Rekha R, Yamuna B (2011) Prevalence and determinants of diabetes mellitus in puduchery, south India. J Pharm Bioallied Sci 3(4): 513-518.

15. Davi WI, Guruaribam SD, Chingakham BS (2011) Traditional herbal Medicine used for the treatment of diabetes in Manipur, India. Research Journal of Pharmaceutical Biological and Chemical Sciences 2: 709-715.

16. Mokdad AH, Ford ES, Bouman BA, Nelson DC, Engelgau MM, et al. (2000) Diabetes trend in US;1990-1998. Diabetes Care 23(9): 12781283.

17. Phillips PJ (2012) Oral glucose tolerance testing. 41(6): 391-393.

18. Barr EL, Zimmet PZ, Welborn TA, Jolley D, Magliano DJ, et al. (2007) Risk of cardiovascular and all-cause mortality in individuals with diabetes mellitus, impaired fasting glucose, and impaired glucose tolerance. The Australian Diabetes, Obesity, and Lifestyle Study (AusDiab). Circulation 116(2): 151-157.

19. Shobha S Rao, Phillip Disraeli, Tamara McGregor (2004) Impaired Glucose Tolerance and Impaired Fasting Glucose. Am Fam Physician 69(8): 1961-1968.

20. Raina EC, Kenealy T (2008) Lifestyle interventions reduced the longterm risk of diabetes in adults with impaired glucose tolerance. Evid Based Med 13(6): 173.
21. Kuo SC, Li Y, Cheng JT (2018) Glucose Tolerance Test Applied in Screening of Anti-Diabetic Agent (S). Current research in Diabetes and Obesity Journal 7(4).

22. (1999) Definition, Diagnosis and Classification of diabetes mellitus and its complications. World Health Organisation (WHO) and International Diabetes Federation (IDF), Geneva, Switzerland.

23. Rivers KL, Cherilyn HM, Mortom AF, Sebastian P, Fredricck PS (2015) Comparison between the Oral Glucose Tolerance Test and the HbA1cAssay for detecting Impaired Glucose Regulation in Bahamian Adolescents. J Diabetes Metab 6: 3.

24. (2007) Oral Glucose Tolerance Test (OGTT) Procedures Manual. National Health and Nutrition Examination Survey (NHANES).

25.(2012) National Population Commission, Nigeria (NPC). Census Report.

26. Patmore J (2009) Oral Glucose Tolerance Tests; "Protocol and Guidance" Hull and Riding Diabetic Network, Hull NHS Teaching Hospitals Trust Retrieved, p. 6-20.

27. Færch K, Borch-Johnsen K, Vaag A, Jørgensen T, Witte D (2010) Sex differences in glucose levels: a consequence of physiology or methodological convenience? The Inter study. Diabetologia 53(5): 858-865.

28. Perreault L, Ma Y, Dagogo-Jack S, Horton E, Marrero D, et al. (2008) Sex Differences in Diabetes Risk and the Effect of Intensive Lifestyle Modification in the Diabetes Prevention Program. Diabetes care 31(7): 1416-1421.

29. Sicree RA, Zimmet PZ, Dunstan WD, Cameron AJ, Welborn TA, et al. (2008) Difference in height Explain gender differences in the response to the oral glucose tolerance test- the AusDiab Study. Diabetic Med 25(3): 296-302.

30. Chamukuttan S, Ram J, Nanditha A, Shetty AS, Sevick MA, et al. (2016) Baseline level of 30-min plasma glucose is an independent predictor of incident diabetes among Asian Indians: analysis of two diabetes prevention programmes. Diabetes Metab Res Rev 32(7): 762-767.

31. Cheng KCYL, Cheng JT (2018) Glucose tolerance test in clinical practice is varied in basic research. International Journal of Diabetes and Clinical Research, p. 5.

32. Rathmann W, Trassburger K, Giani G, Doring A, Meisinger C (2008) Difference in height Explain gender differences in the response to the oral glucose tolerance test. Diabetic Med 25(3): 1374-1375.

\section{Your next submission with Juniper Publishers will reach you the below assets}

- Quality Editorial service

- Swift Peer Review

- Reprints availability

- E-prints Service

- Manuscript Podcast for convenient understanding

- Global attainment for your research

- Manuscript accessibility in different formats

( Pdf, E-pub, Full Text, Audio)

- Unceasing customer service

Track the below URL for one-step submission

https://juniperpublishers.com/online-submission.php 